\title{
Characterization of Proopiomelanocortin mRNA Detected by in situ Hybridization
}

\author{
Jeffrey E. Kelsey, Stanley J. Watson, Sharon Burke, Huda Akil, and James L. Roberts* \\ Mental Health Research Institute, University of Michigan, Ann Arbor, Michigan 48109, and \\ *Department of Biochemistry, Center for Reproductive Sciences, Columbia University, New York, New York 10032
}

In situ hybridization is a method for detecting specific nucleotide sequences by using a labeled complementary nucleic acid probe. We have characterized in situ hybridization in rat pituitary using a cDNA probe directed against a portion of proopiomelanocortin (POMC) mRNA to show its specificity in tissue sections. This characterization includes (1) the size of the target mRNA from tissue processed for in situ hybridization, (2) the dissociation pattern of the cDNA:mRNA hybrid, and (3) quantitation of changes in POMC mRNA levels in the rat pituitary intermediate lobe detected both by in situ hybridization and "dot blot" techniques.

A large body of research in the neurosciences is concerned with the localization and regulation of neurotransmitters. Neuropeptides, which are assuming increasing importance in neurotransmission, have been localized quite thoroughly through immunocytochemistry; yet issues of regulation have proven more complex than for "classical" neurotransmitters, such as acetylcholine and the catecholamines. The advent of recombinant DNA technology has made it possible to study levels of gene expression for many neuropeptides, thus affording an estimation of a cell's biosynthetic readiness to produce a certain peptide, as reflected by the level of mRNA for that peptide. In situ hybridization extends this technology to a more anatomical context, localizing and measuring specific mRNA levels with tissue sections (Hudson et al., 1981). In this respect it is very similar to immunocytochemistry except that one uses labeled DNA or RNA probes in place of antibodies, and detects specific mRNA molecules as opposed to peptides or proteins. In contrast to the more traditional methods of RNA detection or quantitation, such as solution hybridization or solid-phase hybridization (e.g., "dot blots" and Northern blots; Thomas, 1980), in situ hybridization does not disrupt the anatomical localization of its target cells. Thus in situ hybridization allows the detection of mRNA in its anatomical context. Since neural tissue displays such a striking heterogeneity of cell subpopulations, this technique is valuable in exploring questions of local regulation at a singlecell or cell-group level.

Specificity of the cDNA probe for its target (i.e., a specific mRNA) is an important issue for in situ hybridization. Our laboratories have recently demonstrated colocalization of proopiomelanocortin (POMC) mRNA and ACTH immunoreactivity in cells of the arcuate nucleus (Gee et al., 1983) using a POMC cDNA probe. Colocalization of an mRNA with its pep-

Received Nov. 11, 1984; revised May 13, 1985; accepted July 11, 1985.

This work was supported by NIMH Grant MH09059 and the Theophile Raphael Fund (J.K.) and NIDA Grants DA00254 and DA02265 (S.J.W. and H.A.)

Correspondence should be sent to Jeffrey E. Kelsey, the Mental Health Research Institute, University of Michigan, Ann Arbor, Michigan 48109.

Copyright (c) 1986 Society for Neuroscience $0270-6474 / 86 / 010038-05 \$ 02.00 / 0$ tide product is a strong argument for specificity, yet additional characterization of the target mRNA is necessary.

We report here the characterization of the target mRNA of our POMC cDNA probe in rat pituitary by (1) Northern blot comparisons of RNA from fresh tissue and from tissue prepared for in situ hybridization, (2) melting-curve analysis $\left(T_{\mathrm{m}}\right)$ of in situ scctions and RNA bound to nitrocellulose paper from both fresh and perfused tissue, and (3) changes in POMC mRNA levels in rat intermediate lobe induced by haloperidol and detected both by in situ hybridization and dot blot quantitation with equal results. All three lines of evidence support the conclusion that in situ hybridization is an appropriate tcchnique for detecting specific mRNA sequences both anatomically and quantitatively.

\section{Materials and Methods \\ In situ hybridization}

Male Sprague-Dawley rats were anesthetized with sodium pentabarbitol and pcrfused through the aorta, first with $50 \mathrm{ml}$ cold normal saline, then for $20 \mathrm{~min}$ with $4 \%$ neutral buffered formaldehyde. The pituitaries were rapidly removed, frozen in liquid $\mathrm{N}_{2}$ and stored at $-70^{\circ} \mathrm{C}$. Ten-micron sections were cut at $-20^{\circ} \mathrm{C}$ and placed on microscope slides that had been dipped in a $0.15 \%$ gelatin solution. Sections were stored at $-70^{\circ} \mathrm{C}$.

Tissues were warmed to room temperature, immersed in $95 \%$ ethanol and cooled in dry ice/ethanol for $10 \mathrm{~min}$. The sections were hydrated stepwise $(80 \%, 70 \%, 50 \%$ ethanol) at room temperature for 3 min each and then deproteinated in $0.2 \mathrm{~N} \mathrm{HCl}$ for $20 \mathrm{~min}$ (Brahic and Haase, 1978; John et al., 1977). Sections were washed in water and then incubated in 2X-SSC ( $300 \mathrm{~mm} \mathrm{NaCl}$ and $30 \mathrm{~mm}$ Na citrate) for $30 \mathrm{~min}$ at $70^{\circ} \mathrm{C}$ (Brahic and Haase, 1978, Hayashi et al., 1978; Pochet et al., 1981). Tissue sections were water washed, the excess water removed, and $50 \mu$ l of prehybridization buffer containing $1 \mathrm{X}$ Denhardts $(0.02 \%$ Ficoll, $0.02 \%$ polyvinyl pyrillidonc, $10 \mathrm{mg} / \mathrm{ml}$ BSA) and $10 \%$ dextran sulfate in $20 \mathrm{~mm}$ sodium phosphate $\mathrm{pH} 6.5$ was applied. After 10-15 min the prehybridization buffer was removed and replaced with hybridization buffer ( $50 \%$ deionized formamide, $10 \%$ dextran sulfate, $3 \mathrm{X}$ SSC, 1 X Denhardts, $100 \mu \mathrm{g} / \mathrm{ml}$ calf thymus DNA, $1 \mathrm{mg} / \mathrm{ml}$ yeast tRNA, and $100 \mu \mathrm{g} / \mathrm{ml}$ sonicated salmon sperm DNA) containing $30,000 \mathrm{cpm}$ of ${ }^{32}$-labeled 144-base POMC cDNA probe that had been heat denatured. Hybridization was performed for $12-18 \mathrm{hr}$ at $42^{\circ} \mathrm{C}$ in a humid chamber after which the sections were washed in $2 \mathrm{X}-\mathrm{SSC}$ for $1 \mathrm{hr}, 1 \mathrm{X}$ SSC for $1 \mathrm{hr}$, and 0.5X-SSC overnight (Gerhard et al., 1981). All washes were at room temperature. Detection of the signal was by exposure to Kodak XAR-5 x-ray film.

$R N A$ extraction. Total nucleic acids were extracted as described by Rowe et al. (1978) and Chen et al. (1983). The pituitaries were stored at $70^{\circ} \mathrm{C}$ after removal from the animal and then homogenized in 1520 volumes SET buffer ( $1 \%$ SDS, 5 mm EDTA, $10 \mathrm{~mm}$ Tris-Cl, $\mathrm{pH} 7.5$ ) containing proteinase $\mathrm{K}$ (Boehringer-Mannheim) at $65 \mu \mathrm{g} / \mathrm{ml}$. After 90 min at $42^{\circ} \mathrm{C}$, the sample was made $0.03 \%$ in phenylmethylsulfonyl fluoride, organically extracted, and ethanol-precipitated. Tissue from perfused animals was treated identically except for the inclusion of an incubation in normal saline containing $1 \%$ glycine for $2 \mathrm{hr}$ immediately following perfusion and the cutting of the tissue into small pieces. This was found to be necessary to remove excess formaldehyde, which in- 
terfered with the nucleic acid extraction. Presumably, this reflected increased cross-linking of proteins similar to that seen in 30-min perfusions, as mentioned below.

\section{cDNA probe production}

A radiolabeled 144-base cDNA probe, complementary to the beta-lipotropin coding portion of mouse POMC mRNA (Roberts et al., 1979) inserted into the bacteriophage M13mp8, was produced as described by Messing (1983). The primed insert was cut out with the restriction endonuclease Hind III and run on a $4 \%$ polyacrylamide gel to isolate the POMC-complementary sequence. The band was visualized by autoradiography, cut from the gel and eluted overnight in 400-600 $\mu \mathrm{l}$ of $500 \mathrm{~mm}$ ammonium acetate, $10 \mathrm{~mm}$ magnesium acetate, $1 \mathrm{~mm}$ EDTA, and $0.1 \%$ SDS (Maxam and Gilbert, 1980) at $37-42^{\circ} \mathrm{C}$. Sec-butanol was used to reduce the volume of elution buffer, and the probe was ethanolprecipitated after the addition of carrier tRNA. Typically $1 \mu \mathrm{g}$ of M13mp8 produced 5-10 million cpm of single-stranded DNA insert using alpha ${ }^{32} \mathrm{P}$ dCTP $(800 \mathrm{Ci} / \mathrm{mmol}$, New England Nuclear). Probes were also generated by nick-translation of a 923 base-pair mouse cDNA clone (Uhler and Herbert, 1983) using a nick-translation kit from Bethesda Research Laboratories, and were purified on a Sephadex G-50 column.

\section{Dot blot}

Each sample was brought to $10 \mathrm{X}$-SSC with duplicate or triplicate samplcs of $90 \mu \mathrm{l}$ cach, spotted on nitrocellulose (Schleicher and Schuell BA 85 ) preequilibrated in 10X-SSC in a 96-well minifold (Schleicher and Schuell). Samples were drawn through under a vacuum such that 5-7 sec were required for the $90 \mu \mathrm{l}$ to pass through the nitrocellulose. The wells were rinsed with $90 \mu \mathrm{l} 10 \mathrm{X}$-SSC, the nitrocellulose allowed to air dry and then baked for $3-4 \mathrm{hr}$ at $80^{\circ} \mathrm{C}$ in a vacuum oven. The nitrocellulose was prehybridized in a $0.15 \mathrm{ml} / \mathrm{cm}^{2}$ volume, essentially as described by Wahl et al. (1979): 50\% deionized formamide, $5 \mathrm{X}-\mathrm{SSC}$; $5 \mathrm{X}$ Denhardts; $50 \mathrm{~mm}$ sodium phosphate, $\mathrm{pH} 6.5 ; 0.5 \%$ glycine; 100 $\mu \mathrm{g} / \mathrm{ml}$ denatured salmon sperm DNA; and $0.1 \%$ SDS for $2 \mathrm{hr}$ at $42^{\circ} \mathrm{C}$ with constant agitation. The filter was hybridized against $0.5-1 \times 10^{6}$ $\mathrm{cpm}$ of heat-denatured probe $/ \mathrm{ml}$ of hybridization buffer: $50 \%$ deionized formamide, $5 \mathrm{X}-\mathrm{SSC}$; $1 \mathrm{X}$ Denhardts; $20 \mathrm{~mm}$ sodium phosphate, $\mathrm{pH} 6.5$; $100 \mu \mathrm{g} / \mathrm{ml}$ denatured salmon sperm DNA; $0.1 \%$ SDS; $10 \%$ sodium dextran sulfate, $500 \mathrm{~K}$; and $0.5-1$ million cpm of heat-denatured probe/ $\mathrm{ml}$ hybridization buffer. The composition of the prehybridization and hybridization buffers is identical to those commonly reported in the literature and has been found to be very effective in the reduction of nonspecific binding. It was not determined for this application whether each component was necessary for a satisfactory background signal, for the level of background binding was very low. Hybridization was conducted for $12-16 \mathrm{hr}$ at $42^{\circ} \mathrm{C}$ with constant agitation. Following hybridization the filters were washed three times for 5 min each in 2X-SSC, $0.1 \% \mathrm{SDS}$ at room temperature, and twice for $15 \mathrm{~min}$ each in $0.1 \mathrm{X}$ SSC, $0.1 \%$ SDS at $50^{\circ} \mathrm{C}$. The nitrocellulose was exposed to $x$-ray film at $-70^{\circ} \mathrm{C}$ between two intensifying screens. Application of equivalent amounts of liver or cortex nucleic acids (two tissues that do not express the POMC gene) displayed very little, if any, background binding which, when present, was subtracted from the pituitary samples. Treatment of pituitary samples with DNase-free RNase showed total abolition of the signal. This indicates that the hybridization signal was indeed from POMC mRNA and not from contaminating genomic POMC DNA.

$\mathrm{T}_{m}$ analysis. Either sections of nitrocellulose with bound RNA or tissue slices that had bound the labeled cDNA probe were exposed to $\mathrm{x}$-ray film to establish a baseline and then incubated at the indicated temperature for 10 or $60 \mathrm{~min}$, respectively, in $0.1 \mathrm{X}-\mathrm{SSC}, 0.1 \% \mathrm{SDS}$. Matched sections were washed at $37^{\circ} \mathrm{C}$ (in situ) or $45^{\circ} \mathrm{C}$ (dot blots) and used for controls.

Northern blots. RNA was separated on $1 \%$ agarose gels containing formaldehyde as a denaturant, as described by Maniatis et al. (1982). The contents of the gel were then passively transferred to nitrocellulose paper in 20X-SSC overnight (Thomas, 1980), air dried, baked at $80^{\circ} \mathrm{C}$ for $3 \mathrm{hr}$, and then prehybridized, hybridized, and washed as described for the dot blots.

Drug treatment. POMC cells in the intermediate lobe are normally under tonic dopaminergic inhibition (Tilders and Smelik, 1978). To produce an increase in POMC mRNA levels (Chen et al., 1983), animals were given $2 \mathrm{mg} / \mathrm{kg}$ haloperidol (a dopamine-receptor antagonist) daily for $4 \mathrm{~d}$ and then sacrificed on the 5th $\mathrm{d}$. Control animals received an equal volume of vehicle injections.

Densitometry. The intensity of the hybridization signal on x-ray film

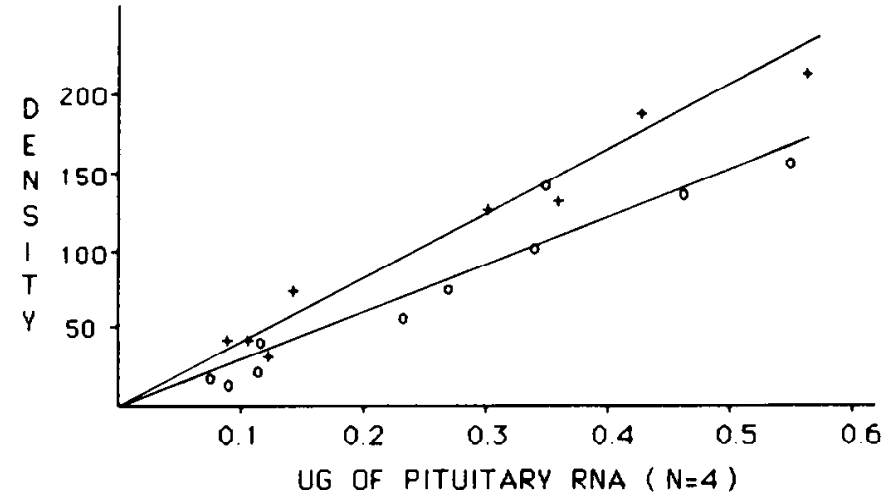

Figure 1. Density of spots after autoradiography of dot-blotted RNA from fresh $(+)$ or perfused $(O)$ tissue. Nucleic acids were extracted from tissue, treated with DNase I, and the RNA was spotted on nitrocellulose paper in the concentrations shown on the $x$-axis and probed with a ${ }^{32} \mathrm{P}$ POMC probe. Each point represents one concentration from a single pituitary that was spotted in duplicate. Pituitaries from four animals in each group were used. A background value of 5 (as determined by applying a fivefold excess of nucleic acids from liver and cortex on the nitrocellulose) was subtracted from each point. The line is a least-squares best fit.

for both dot blots and in situ sections was quantitated with a densitometer constructed in the electronics shop of the Mental Health Research Institutc following the design of Dauth et al. (1979). The exposure time of the sample to the $x$-ray film was carefully monitored, and several different concentrations of the same sample were applied to the nitrocellulose paper to ensure that the signal was within the linear response range of the film.

\section{Results}

We first wanted to determine the amount of POMC mRNA present in tissue that had been perfused with formaldehyde to assess any change in concentration brought about by the perfusion. Figure 1 shows the results of a dot blot assay comparing hybridizable POMC mRNA from fresh and perfused tissue. Perfusion of the animal with $4 \%$ buffered formaldehyde prior to nucleic acid extraction resulted in a slight decrease in the recovery of POMC mRNA. The process of fixation itself, however, still left a large percentage of hybridizable POMC mRNA in the tissue. When the perfusion time was increased to $30 \mathrm{~min}$, the amount of POMC mRNA that could be extracted and visualized on a Northern blot fell to almost zero. We believe this is due to the greater cross-linking of proteins that occurs with longer fixation times which, in effect, physically "trap" the long nucleic acids in the tissue to an extent far greater than 20 -min perfusion. This "trapping" manifests itself as the large organic/ aqueous interface seen on the first organic extraction of the perfused tissue. This great increase in cross-linking appears to be detrimental for in situ hybridization only as the size of the probe gets very large (Angerer and Angerer, 1981), for the application of smaller, synthetic oligonucleotide probes in other studies in our laboratory does not have this effect (Lewis et al., in press). The size of the extractable POMC mRNA in perfused tissue was determined with Northern blot analysis (Fig. 2). Only one band from perfused tissue (lane A) was detectable, migrating at approximately 1200 bases (as determined with a denatured 123-bp ladder from Bethesda Research Laboratories), which is similar to the size observed in samples from fresh tissue (lane B) and identical to that reported by others (Civelli et al., 1982). The presence of only one band indicates that the process of perfusion leads to very little detectable degradation, which could confound attempts at quantitation.

To determine the specificity of our cDNA probe for POMC mRNA, we performed a series of melting-point experiments 


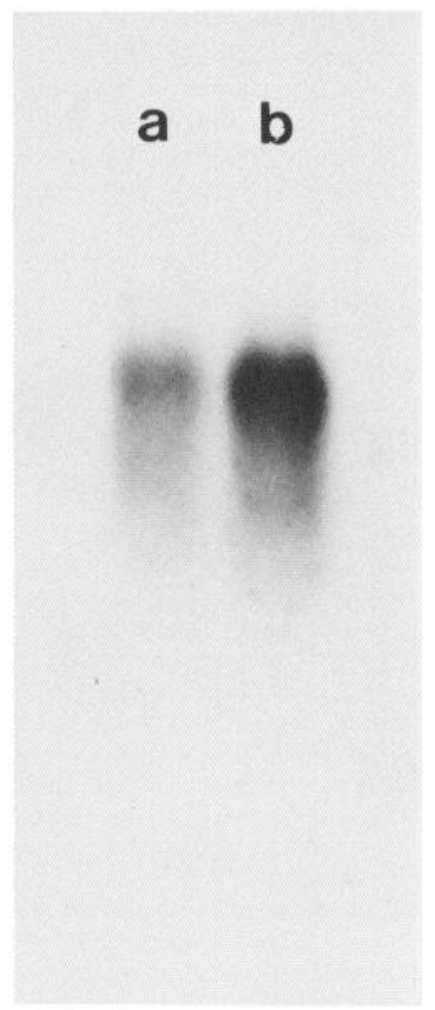

Figure 2. Northern blot of POMC mRNA. Ten percent of pituitary RNA after SET extraction was separated on a $1 \%$ agarose gel containing formaldehyde, transferred to nitrocellulose, and probed with a ${ }^{32} \mathrm{P}$ labeled POMC probe, as described in the text. Both RNA from the formaldehyde-perfused tissue (lane $a$ ) and from fresh tissue (lane $b$ ) migrated at approximately 1200 bases.

( $T_{\mathrm{m}}$ determinations) on both RNA bound to nitrocellulose paper and on in situ tissue sections. In general, if two sequences are closely matched (e.g., the cDNA probe and the POMC mRNA), as the temperature is raised (under stable salt conditions) the cDNA:RNA hybrids should begin to slowly dissociate and then undergo a sharp transition period when almost all the hybrids dissociate within a narrow temperature range. Figure 3 shows the results of these experiments with the percentage of signal lost plotted as a function of temperature. All three conditions displayed similar $T_{\mathrm{m}}$ of $71.8,71.5$, and $70.8^{\circ} \mathrm{C}$ for nitrocellulose-bound perfused-tissue RNA, fresh-tissue RNA, and in situ hybridization tissue sections, respectively. All three temperatures are close to the theoretical $T_{\mathrm{m}}$ of $71^{\circ} \mathrm{C}$ as calculated by the formula

$$
\begin{aligned}
T_{\mathrm{m}}= & 16.6 \log [\mathrm{Na}]+(41 \times \text { fraction } \mathrm{GC} \text { base pairs }) \\
& +81.5^{\circ} \mathrm{C}-1{ }^{\circ} \mathrm{C} / 1 \% \text { mismatch } \\
& -[300+(2000 \times[\mathrm{NA}]) / \text { probe length }]
\end{aligned}
$$

(Bonner et al., 1973; Britten et al., 1974; Cantor and Schimmel, 1980). The values for our probe are $[\mathrm{Na}]=0.0165 \mathrm{~m}$; fraction $\mathrm{GC}$ bp $=0.604 ; \%$ mismatch $=3.4$; and probe length, 144 bases.

Figure 4 shows the results of administration of haloperidol ( $2 \mathrm{mg} / \mathrm{kg}$ ) for $4 \mathrm{~d}$ as determined by both dot blots and in situ hybridization. Animals receiving haloperidol showed an increase in POMC mRNA levels of approximately $50 \%$ over control animals, as assayed by dot blots (top panel). The bottom panel shows representative sections from a haloperidol-treated or control animal processed for in situ hybridization. Approximately 50 neurointermediate lobe-containing sections per pituitary were obtained. A number of these sections were sampled for each animal and the densities of the sections for each were pooled. This allowed for a thorough sampling of each pituitary

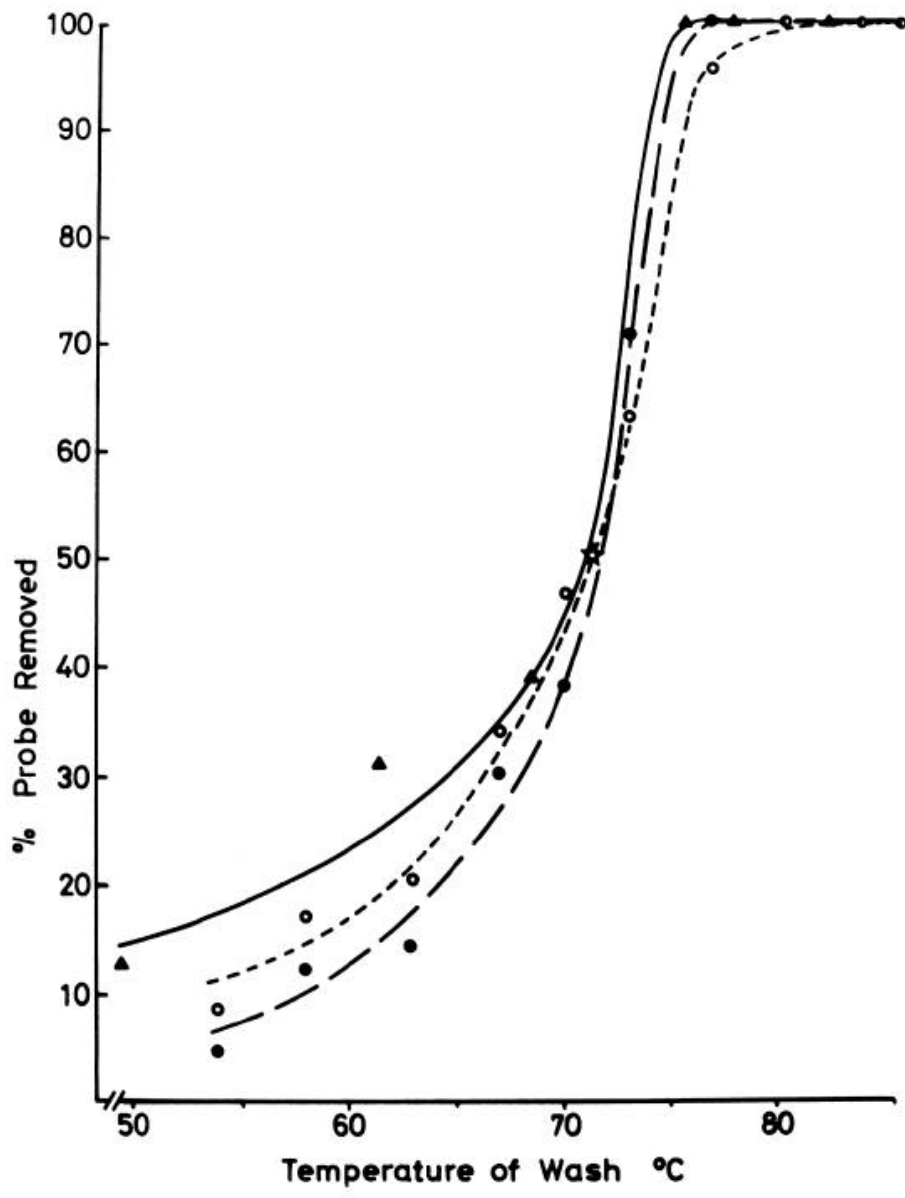

Figure 3. $T_{\mathrm{m}}$ analysis of in $\operatorname{situ}\left(\boldsymbol{\Lambda}, 70.8^{\circ} \mathrm{C}\right)$ and dot blot hybridization from fixed $\left(0,71.8^{\circ} \mathrm{C}\right)$ and fresh $\left(0,71.5^{\circ} \mathrm{C}\right)$ tissue. Each point is $2 \%$ of pituitary nucleic acids. $T_{\mathrm{m}}$ analysis was performed twice on different samples with nearly identical results each time. In all conditions the samples were hybridized with a 144 base ${ }^{32} \mathrm{P}$-labeled POMC probe and exposed to $x$-ray film. Samples were then paired, with one sample undergoing a wash at the temperature indicated on the $x$-axis, the other a control wash at 37 or $45^{\circ} \mathrm{C}$ (see text). At the end of the wash the samples were allowed to air dry and again exposed to $x$-ray film. The amount of radioactivity lost compared to the control sample is plotted on the $y$-axis, as determined by densitometry. The very similar curves and nearly identical $T_{\mathrm{m}}$ 's indicate that all three conditions are most likely the same hybrid $\left[T_{\mathrm{m}}\right.$ (theoretical): $\left.\hat{\jmath}, 71.0^{\circ} \mathrm{C}\right]$.

across a group of animals. In situ hybridization also demonstrated a $50 \%$ increase in POMC mRNA levels in the intermediate lobe, in close agreement with the data from the dot blot assay.

\section{Discussion}

We have shown that the target of in situ hybridization is most likely the RNA species we had intended to detect, as indicated by the intact nature of that RNA following formaldehyde perfusion and extraction. POMC mRNA was also quantitated, sized, and physiologically altered, and followed the expected set of hybridization kinetics. Even though this was suggested previously by colocalization of POMC peptide products detected by immunocytochemistry and an in situ hybridization signal in serial sections (Gee et al., 1983), this is a direct characterization of the target RNA. Northern blots and $T_{\mathrm{m}}$ analysis have shown that the RNA from perfused tissue detected by our POMC probe is of the proper size and most likely of only one sequence, as indicated by the narrow temperature range of hybrid dissociation (Fig. 3). 

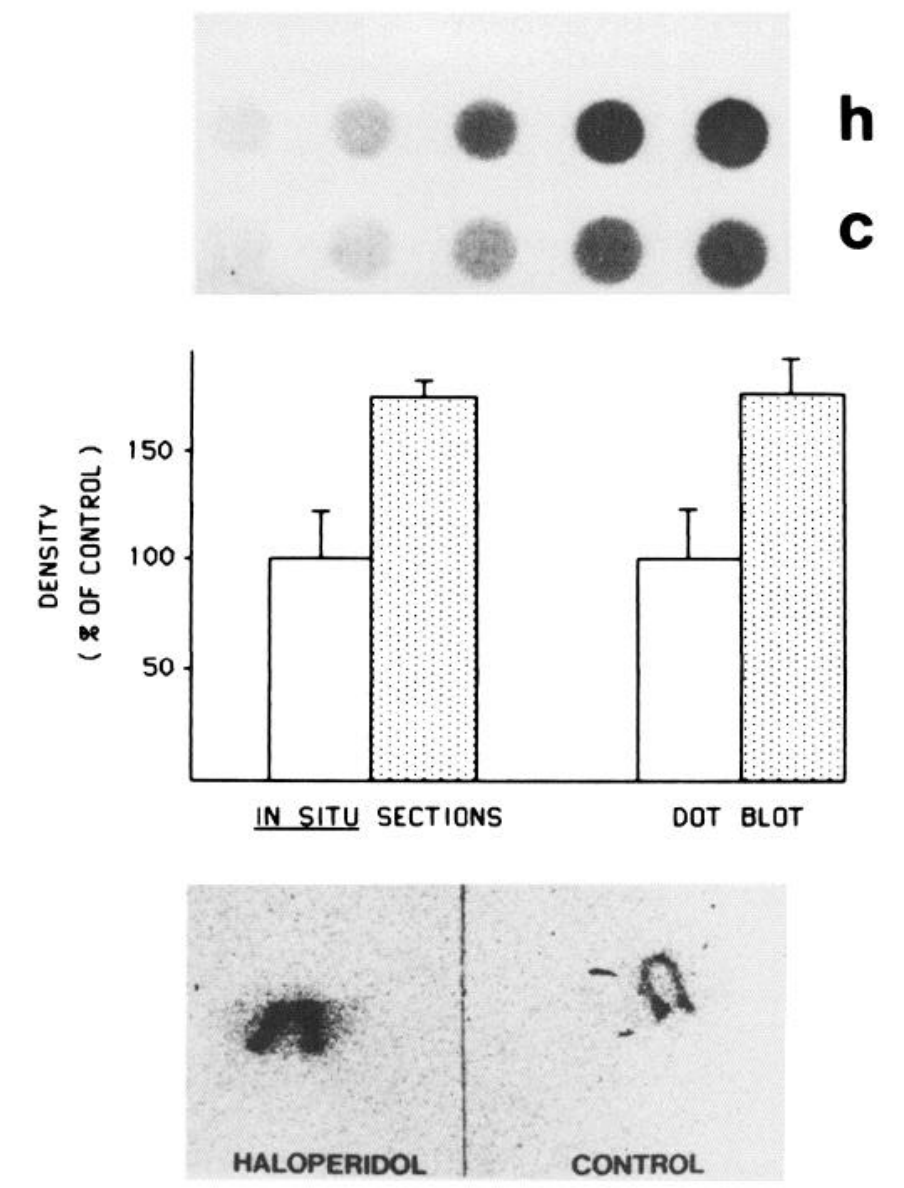

Figure 4. Top and bottom, Dot blots or in situ sections from the pituitaries of animals that received either haloperidol $(2 \mathrm{mg} / \mathrm{kg})$ for 4 $\mathrm{d}$ prior to sacrifice or an equal volume of vehicle injection. For the dot blots, the top row is from an animal that received haloperidol $(h)$, the bottom row is from a control animal $(c)$. From left to right, the amount of nucleic acid spotted is $0.675,1.35,2.7,4.7$, or $6.7 \%$ of a pituitary. Each concentration was spotted in duplicate. The in situ sections were processed as described in the text, hybridized with equal amounts of radioactive probe and washed as described in the text. The intermediate lobe is the horseshoe-shaped structure. These two sections are from different parts of the pituitary, but the densities graphed in the middle panel represent many sections from each animal. The middle panel shows the densities of the dot blots and in situ sections from four animals each for vehicle injection (open bar) or haloperidol injection (stippled bar).

Finally, in situ hybridization has been demonstrated to be a useful tool for specific mRNA quantitation. Treatment of rats with haloperidol for $4 \mathrm{~d}$ prior to sacrifice produced an increase in POMC mRNA levels of approximately $50 \%$, as determined by both in situ hybridization and the dot blot assay in the pituitary. Additionally, in situ hybridization localized this increase to the intermediate lobe, as would be expected (Chen et al., 1983).

At a broader level, it seems that in situ hybridization is a unique method for anatomical localization and quantitation in that it allows one to study the distribution of specific mRNA sequences in the context of surrounding cells, and at the same time to fully characterize the target of the cDNA probe. This contrasts favorably with immunocytochemistry, in which fixation alters protein antigens. Several general nucleic acid methods (including the one discussed in this paper) suggest that formaldehyde fixation does not appear to alter mRNA with regard to size, mobility in a gel, or ability to hybridize to cDNA.
The quantitative study of cellular mRNA offers a powerful vantage point for investigating the long-term or chronic readiness of a cell to synthesize neuropeptides, as mRNA levels are the intermediate between transcriptional and translational activity. Although mRNA levels cannot address the issue of posttranslational processing, they can offer insights that would otherwise be lost by measuring only peptide levels. For example, Tang et al. (1983) showed a fourfold increase in striatal proenkephalin mRNA after chronic haloperidol treatment, yet only a twofold increase in met-enkephalin peptide levels. Clearly this difference in induction could occur in a number of different ways, such as changes in translation rates, degradation, or release, yet the measurement of peptide content alone would have underestimated the changes taking place. Thus, in situ hybridization should be a very valuable tool for the study of localized changes in biosynthetic status in a tissue as heterogeneous as the brain, where microdissection might either prove impractical or mask changes in very small groups of cells. The general logic described above for the characterization of $i$ situ hybridization is directly applicable to brain tissue, as has been demonstrated by the use of oligonucleotide probes to detect changes in vasopressin mRNA following salt loading in the supraoptic and paraventricular nuclei (Sherman et al., 1985). It is our experience that the changes necessary to apply in situ hybridization to the brain involve considerations of sensitivity and mRNA complexity, which require careful consideration of probe construction and labeling.

\section{References}

Angerer, L. M., and R. C. Angerer (1981) Detection of poly A+ RNA in sea urchin eggs and embryos by quantitative in situ hybridization. Nucleic Acids Res. 9: 2819-2840.

Bonner, T. I., D. J. Brenner, B. R. Neufeld, and R. J. Britten (1973) Reduction in the rate of DNA reassociation by sequence divergence. J. Mol. Biol. 81: 123-135.

Brahic, M., and A. T. Haase (1978) Detection of viral sequences of low reiteration frequency by in situ hybridization. Proc. Natl. Acad. Sci. USA 75: 6125-6129.

Britten, R. J., D. E. Graham, and B. R. Neufeld (1974) DNA sequence analysis by reassociation. In Methods in Enzymology, L. Grossman and K. Moldave, eds., Vol. 29, pp. 363-418, Academic, New York.

Cantor, C. R., and P. R. Schimmel (1980) Biophysical Chemistry, p. 1155 , W. H. Freeman, San Francisco.

Chen, C. L., F. T. Dione, and J. L. Roberts (1983) Regulation of the pro-opiomelanocortin mRNA levels in rat pituitary by dopaminergic compounds. Proc. Natl. Acad. Sci. USA 80: 2211-2315.

Civelli, O., N. Birnberg, and E. Herbert (1982) Detection and quantitation of pro-opiomelanocortin mRNA in pituitary and brain tissues from different species. J. Biol. Chem. 257: 6783-6787.

Dauth, G. W., K. A. Frey, and S. Gilman (1979) A densitometer for quantitative autoradiography. J. Neurosci. Meth. 9: 243-251.

Gee, C. E., C. L. Chen, J. L. Roberts, R. Thompson, and S. J. Watson (1983) Identification of proopiomelanocortin neurons in rat hypothalamus by in situ cDNA-mRNA hybridization. Nature 306: 374 376.

Gerhard, D. S., E. S. Kawaski, F. C. Bancroft, and P. Szabo (1981) Localization of a unique gene by direct hybridization in situ. Proc. Natl. Acad. Sci. USA 78: 3755-3759.

Hayashi, S., I. C. Gillam, A. D. Delaney, and G. M. Tenner (1978) Acetylation of chromosome squashes of Drosophila Melanogaster decreases the background in autoradiographs from hybridization with (125I) labeled RNA. J. Histol. Cytol. 26: 677-679.

Hudson, P., J. Penschow, J. Shine, G. Ryan, H. Niall, and J. Coghlan (1981) Hybridization histochemistry: Use of recombinant DNA as a "homing probe" for tissue localization of specific mRNA populations. Endocrinology 108: 353-356.

John, H. A., M. Patrinou-Georgoulas, and K. W. Jones (1977) Detection of myosin heavy chain mRNA during myogenesis in tissue culture by in vitro and in situ hybridization. Cell 12: 501-508.

Lewis, M. E., T. G. Sherman, and S. J. Watson (in press) In situ hybridization histochemistry with synthetic oligonucleotides: Strategies and methods. Peptides. 
Maniatis, T., E. F. Fritsch, and J. Sambrook (1982) Molecular Cloning-A Laboratory Manual, Cold Spring Harbor Laboratory, Cold Spring Harbor, NY.

Maxam, A. M., and W. Gilbert (1980) Sequencing end labeled DNA with base-specific chemical cleavages. In Methods in Enzymology, L. Grossman and K. Moldave, eds., Vol. 65, pp. 499-560, Academic, New York

Messing, J. (1983) New M13 vectors for cloning. In Methods in Enzymology, R. Wu, L. Grossman, and K. Moldave, eds., Vol. 101, pp. 20-77, Academic, New York.

Pochet, R., H. Brocas, G. Vassart, G. Toubeau, H. Seo, S. Refetoff, J. E. Dumont, and J. L. Pasteels (1981) Radioautographic localization of prolactin messenger RNA on histological sections by in situ hybridization. Brain Res. 211: 433-438.

Roberts, J. L., P. H. Seeburg, J. Shine, E. Herbert, J. D. Baxter, and H. M. Goodman (1979) Corticotropin and beta-endorphin: Construction and analysis of recombinant DNA complementary to mRNA for the common precursor. Proc. Natl. Acad. Sci. USA 76: 21532157.

Rowe, D. W., R. C. Moen, J. M. Davidson, P. H. Byers, P. Bornstein, and R. D. Palmiter (1978) Correlation of procollagen mRNA levels in normal and transformed chick embryo fibroblasts with different rates of procollagen synthesis. Biochemistry 17: 1581-1590.
Sherman, T. G., H. Akil, and S. J. Watson (1985) Vasopressin mRNA expression: An in situ and northern blot analysis. In Vasopressin, $\mathrm{M}$. Schrier, ed., Raven, New York.

Tang, F., E. Costa, and J. P. Schwartz (1983) Increase of proenkephalin mRNA and enkephalin content of rat striatum after daily injection of haloperidol for 2 to 3 weeks. Proc. Natl. Acad. Sci. USA 60:38413844.

Thomas, P. S. (1980) Hybridization of denatured RNA and small DNA fragments transferred to nitrocellulose. Proc. Natl. Acad. Sci. USA 77: 5201-5205.

Tilders, F. J. H., and P. G. Smelik (1978) Effects of hypothalamic lesions and drugs interfering with dopaminergic transmission on pituitary MSH content of rats. Neuroendocrinology 25: 275-290.

Uhler, M., and E. Herbert (1983) Complete amino acid sequence of mouse pro-opiomelanocortin derived from the nucleotide sequence of pro-opiomelanocortin cDNA. J. Biol. Chem. 258: 257-261.

Wahl, G. M., M. Stern, and G. R. Stark (1979) Efficient transfer of large DNA fragments from agarose gels to diazobenzyloxymethylpaper and rapid hybridization by using dextran sulfate. Proc. Natl. Acad. Sci. USA 76: 3683-3687. 